УДК 330.341 .13

Омельченко А. I.

Національний технічний університет Украйни «КПІ»

\title{
ТЕХНОЛОГІЧНИЙ РОЗВИТОК ЯК СКЛАДОВА ІННОВАЦІЙНОГО РОЗВИТКУ ПРОМИСЛОВОГО ПІДПРИЕМСТВА
}

\section{ТЕХНОЛОГИЧЕСКОЕ РАЗВИТИЕ КАК СОСТАВЛЯЮЩАЯ ИННОВАЦИОННОГО РАЗВИТИЯ ПРОМЫШЛЕННОГО ПРЕДПРИЯТИЯ}

\section{TECHNOLOGICAL INNOVATION DEVELOPMENT AS A PART OF INDUSTRIAL ENTERPRISES}

Функиіонування вітчизняних промислових підприємств визначається господарськоекономічними умовами, сприятливість чи несприятливість яких визначається рівнем невизначеності зовнішнього середовища. Тому діяльність підприємств повинна спрямовуватись не лише на виживання в умовах конкурениії, але й на процес безперервного та ефективного розвитку. Технологічний розвиток в изьому випадку стає важливим прочесом, спрямованим на вирішення зазначених завдань. Ціллю статті є дослідження проблем та шляхів техніко-технологічного розвитку промислових підприємств. У статті проаналізовано динаміку впровадження техніко-технологічних інновацій на вітчизняних промислових підприємствах та розглянуто фактори, які перешкоджають впровадженню прогресивних технологій. В результаті проведених досліджень авторами визначено ефективні заходи щьодо успішного техніко-технологічного розвитку, запропоновано дієву систему показників для комплексної оцінки технологічного потенціалу підприємства.

Проаналізувавши сочіально-економічну, політичну та екологічну ситуацію в крайні, зроблено висновок, щзо найефективнішими умовами технологічного розвитку в сучасних умовах буде екологічно-спрямований розвиток. Це дозволить підприємствам забезпечити сочіальну активність та економічну ефективність.

Ключові слова: техніко-технологічний розвиток, технологічні інновації, технологічний потенціал, екологічність, еко-інновації, екологічно спрямований розвиток.

Функиионирование отечественных промышленных предприятий определяется хозяйственно-экономическими условиями, восприимчивость или неблагоприятные условия которых определяются уровнем неопределенности внешней среды. Поэтому деятельность предприятий должна быть направлена не только на выживание в условиях конкуренции, но и на процесс непрерывного и эффективного развития. Технологическое развитие в этом случае становится важным процессом, направленным на решение указанных задач. Целью статьи является исследование проблем и путей техникотехнологического развития промылиленных предприятий. В статье проанализирована динамика внедрения технико-технологических инноваџий на отечественных промышиленных предприятиях и рассмотрены факторы, которые препятствуют внедрению прогрессивных технологий. В результате проведенных исследований авторами определень эффективные меры по успешного технико-технологического развития, предложено действенную систему показателей для комплексной оценки технологического потенциала предприятия. 
Проанализировав сочиильно-экономическую, политическую и экологическую ситуацию в стране, сделан вывод, что наиболее эффективными условиями технологического развития в современных условиях будет экологически направленное развитие. Это позволит предприятиям обеспечить социальную активность и экономическую эффективность.

Ключевые слова: технико-технологическое развитие, технологические инновации, технологический потенциал, экологичность, эко-инновации, экологически направленное развитие.

The domestic industry defined business and economic conditions or unfavourable auspiciousness which is derived from the uncertainties of the environment. Therefore, the activities of enterprises should be directed not only to survive in a competitive environment, but also the process of continuous and effective development. Technological developments in this case is an important process that attempts to solve these problems. The purpose of the article is to study the problems and ways of technical and technological development industry. The article analyses the dynamics of implementation of technical and technological innovations in domestic industrial and the factors that hinder the implementation of advanced technologies. As a result of research sponsored defined effective measures for successful technical and technological development, proposed an effective system of indicators for integrated assessment of the technological potential of the company.

After analysing the socio-economic, political and environmental situation in the country, concluded that the most effective terms of technological development in modern terms is an environmentally-focused development. This will allow companies to provide social activities and economic efficiency.

Keywords: technical and technological development, technological innovation, technological capacity, environmentally friendly, eco-innovation, eco-focused development.

Вступ. В сучасних умовах господарювання інноваційний розвиток $\epsilon$ основним ресурсом соціально-економічного розвитку як окремого промислового підприємства так і країни в цілому. Технологічний розвиток повинен розглядатись як базова складова інноваційного розвитку, тому що ефективність функціонування вітчизняних промислових підприємств в сучасних умовах неможлива без застосування прогресивних технологій, новітньої техніки та інноваційної організації ведення бізнесу. Постійний техніко-технологічний розвиток підприємства забезпечить його високі конкурентні переваги на ринку та дозволить ефективно здійснювати виробничу діяльність. Крім цього, забезпечення конкурентних позицій, завдяки впровадженню наукомісткої продукції $\epsilon$ важкодоступним для вітчизняних підприємств оскільки потребує значних фінансових вкладень. Саме тому забезпечення інноваційного розвитку на основі залучених технологій, їх акумуляція та застосування для реалізації заходів 3 економії ресурсів, оптимізації виробництва є актуальним.

Питаннями проблем та шляхів техніко-технологічного розвитку промислових підприємств, його теоретичними та практичними аспектами займаються чимало наукових вчених економістів. Серед них роботи Л.І. 
Федулової [1], О.Г. Шевлюги та О.М. Олефіренка [2], І.В. Гонтаревої [4], Г.В. Рачинської та Л.С. Лісовської [5] та інш. Однак питання ефективного та безперервного розвитку підприємства на основі технологічних інновацій досі залишається відкритим та потребує детального дослідження.

Постановка завдання. Метою роботи $є$ узагальнення теоретичних $\mathrm{i}$ обгрунтування науково-практичних підходів до технологічного розвитку промислових підприємств на засадах еко-інновацій.

Методологія. Під час написання статті були використані такі методи дослідження як аналіз, узагальнення, порівняння, спостереження. В роботі було використано графічний метод для наочного відображення математичних даних та економіко-математичні методи економічного обгрунтування доцільності впровадження запропонованих вдосконалень. Також в роботі використані такі методи аналізу, як аналіз показників комплексної оцінки інноваційного потенціалу та запропоновано адаптовану систему показників екологічності для виявлення найефективнішого шляху інноваційного розвитку промислового підприємства.

Результати дослідження. Технологічний розвиток підприємства визначається ефективністю відтворення інновацій, що відображаються в основних факторах виробництва, в структурі управління ними, а також в новій продукції [1]. Він повинен спрямовуватись, з одного боку, на підтримку в належному стані та розвиток техніко-технологічної бази промислового підприємства: модернізація, технічне переозброєння, реконструкція, розширення, нове будівництво, а з іншого - на стабільне використання нових прогресивних технологій (технологічних інновацій) [2].

Створення та освоєння нових технологій допомагає скоротити час розроблення та запровадження у виробництво нових продуктів, а це, своєю чергою, дає змогу активніше реагувати на потреби кожного потенційного клієнта. Інноваційні технології уможливлюють також заощадити робочу силу, підвищити технологічну гнучкість виробництва, поліпшити умови та безпеку праці, сприяють подоланню дефіциту робочої сили зі спеціальною освітою. Зрозуміло, що технологічні інновації потребують витрат матеріальних, організаційних та фінансових ресурсів [5].

Отже, ефективний техніко-технологічний розвиток сприяє розвитку підприємства, галузі і країни в цілому. Він дозволить підвищити ефективність господарської діяльності і надасть певні умови для покращення якості життя людей у країні [2].

Розглянемо фактори, які перешкоджають впровадженню нових технологій на підприємстві (рисунок) 


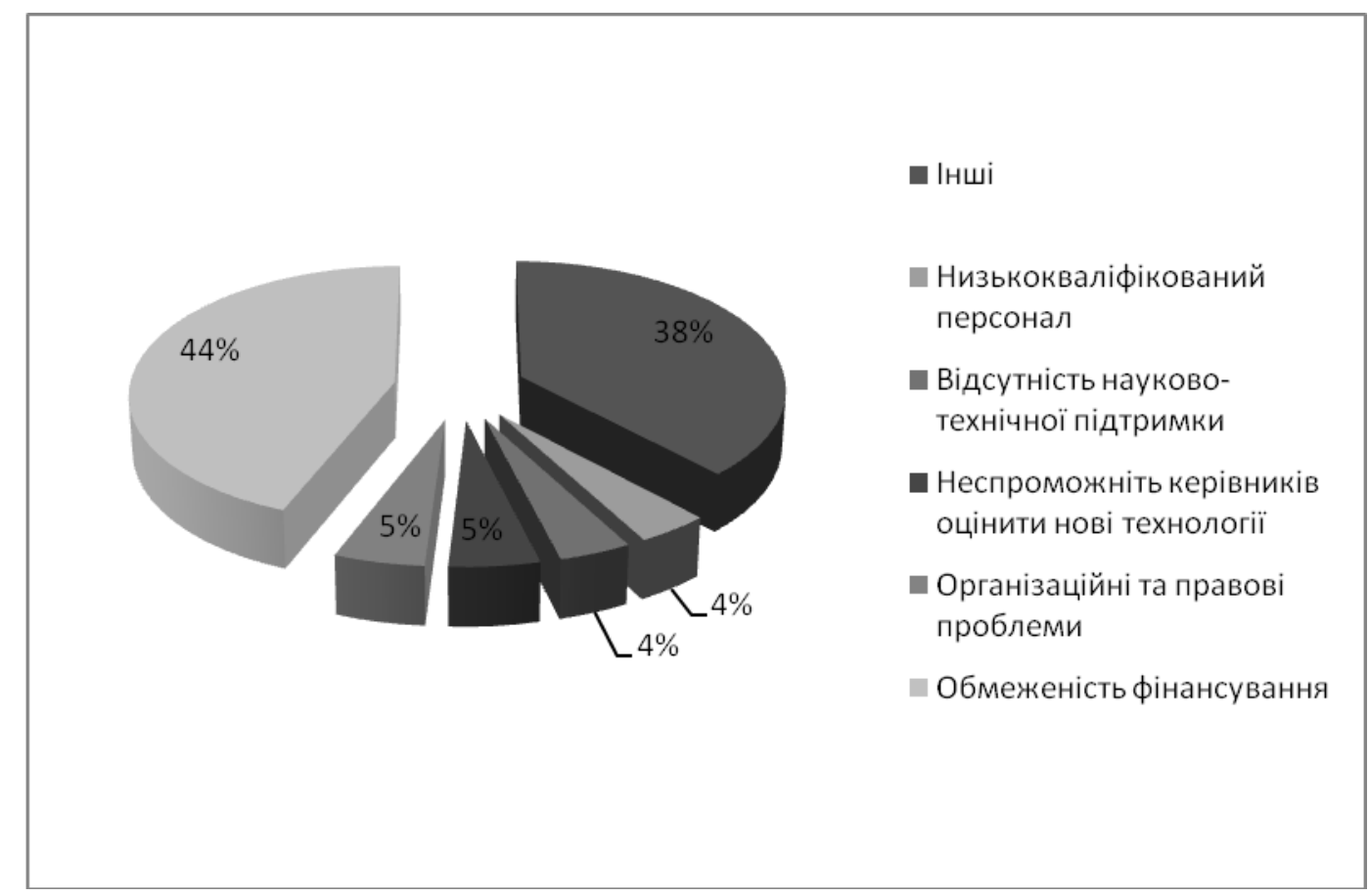

Рисунок. Чинники, що перешкоджають впровадженню нових технологій на підприємстві

\section{Джерело [4]}

Аналізуючи дані, представлені в діаграмі, можна дійти висновку, що найвагомішим фактором, який перешкоджав впровадженню нових технологій $\epsilon$ обмеженість фінансування. Про це зазначили 44\% підприємств. Організаційні та правові проблеми, а також неспроможність керівників різного рівня оцінити нові технології заважають впровадженню прогресивних технологій майже однаково, а саме на рівні $5,2 \%$ та 4,9\% відповідно. Також майже однаковою мірою заважали впроваджувати передові промислові технології такі фактори, як відсутність науково-технічної підтримки $(4,2 \%)$ та низько кваліфікований персонал $(3,4 \%)$.

Отже, проаналізувавши отримані дані можна зробити висновок про те, що в Україні спостерігається тенденція до зниження потенціалу технікотехнологічної бази підприємств. Тому іiі оновлення повинно стати першочерговою умовою розвитку як окремого підприємства, так i національного господарства у цілому.

Визначимо дієві заходи, які необхідно здійснювати керівництву підприємства для успішного техніко-технологічного розвитку:

- $\quad$ заміна застарілого обладнання, машин та інших основних засобів на прогресивні технології;

- перехід до використання прогресивних технологій і новітньої техніки: енерго- та паливнозберігаючої, маловідходної або безвідходної; 
- перехід до інноваційних моделей ведення бізнесу, таких як «зелені» бізнес моделі;

- підвищення кваліфікаційного рівня працівників: від адміністративного персоналу до обслуговуючого;

- $\quad$ придбання виключно якісних та провідних основних засобів;

- $\quad$ в використання у виробництві лише якісної сировини та матеріалів;

- застосування інноваційних методів організації виробництва та робочого процесу для максимально ефективної роботи.

Для здійснення всіх вище перелічених заходів спершу треба визначити, чи спроможне підприємство до вдосконалення. Для цього необхідно провести оцінку можливостей підприємства до інноваційного розвитку, частиною якого i $\epsilon$ технологічний розвиток підприємства. Таким чином, для визначення інноваційного потенціалу підприємства, до системи показників за різними складовими слід віднести показники, представлені в табл. 1.

Таблиця 1

Система показників для комплексної оцінки інноваційного потенціалу підприсмства

\begin{tabular}{|c|c|c|}
\hline Показник & Позначення & Формула \\
\hline \multicolumn{3}{|c|}{ Фінансова складова } \\
\hline $\begin{array}{c}\text { Доля внутрішніх витрат на НДДКР і } \\
\text { придбання технологій в загальних витратах } \\
\text { на виробництво }\end{array}$ & $\mathrm{K}_{1}$ & $\mathrm{~K}_{1}=\frac{\mathrm{B}_{\text {нддкRp }}+\mathrm{B}_{\mathrm{T}}}{\mathrm{B}_{\text {3ar }}}$ \\
\hline Наукоємність продукції, що виробляється & $\mathrm{K}_{2}$ & $\mathrm{~K}_{2}=\frac{\mathrm{B}_{\text {нддкр }}}{V_{\text {пр }}}$ \\
\hline $\begin{array}{c}\text { Показник забезпеченості інтелектуальною } \\
\text { власністю }\end{array}$ & $\mathrm{K}_{3}$ & $\mathrm{~K}_{3}=\frac{\mathrm{B}_{\mathrm{iz}}}{\mathrm{B}_{3}}$ \\
\hline $\begin{array}{c}\text { Доля витрат на придбання нематеріальних } \\
\text { активів в загальних витратах на дослідження } \\
\text { та розробки }\end{array}$ & $\mathrm{K}_{4}$ & $\mathrm{~K}_{4}=\frac{\mathrm{B}_{\text {Ha }}}{\mathrm{B}_{\text {ндभкр }}}$ \\
\hline $\begin{array}{c}\text { Доля витрат на підвищення кваліфікації } \\
\text { кадрів в загальному обсязі витрат на } \\
\text { дослідження та розробки }\end{array}$ & $\mathrm{K}_{5}$ & $\mathrm{~K}_{5}=\frac{\mathrm{B}_{\mathrm{oK}}}{\mathrm{B}_{\text {ндДКр }}}$ \\
\hline Державні джерела фінансування НДДКР & $\mathrm{K}_{6}$ & $\mathrm{~K}_{6}=\frac{\mathrm{BД}}{\mathrm{B}_{\text {нддкр }}}$ \\
\hline \multicolumn{3}{|c|}{ Кадрова складова } \\
\hline $\begin{array}{c}\text { Доля робітників, зайнятих дослідженнями та } \\
\text { розробками в загальній кількості } \\
\text { працюючих }\end{array}$ & $\mathrm{K}_{7}$ & $\mathrm{~K}_{7}=\frac{\mathrm{Ч}_{\text {нддкр }}}{\mathrm{U}_{\text {заг }}}$ \\
\hline
\end{tabular}




\begin{tabular}{|c|c|c|}
\hline $\begin{array}{c}\text { Забезпеченість кадрами найвищої } \\
\text { кваліфікації }\end{array}$ & $\mathrm{K}_{\mathrm{B}}$ & $\mathrm{K}_{\mathrm{B}}=\frac{\mathrm{Y}_{\mathrm{BK}}}{\mathrm{Ч}_{\text {нддкр }}}$ \\
\hline $\begin{array}{c}\text { Рівень заробітної плати науково-технічних } \\
\text { робітників }\end{array}$ & $\mathrm{K}_{9}$ & $\mathrm{~K}_{9}=\frac{3 \Pi_{\mathrm{HTc}}}{3 \Pi_{\mathrm{E}}}$ \\
\hline \multicolumn{3}{|c|}{ Матеріально-технічна складова } \\
\hline $\begin{array}{c}\text { Техніко-технологічна база, призначена для } \\
\text { НДДКР }\end{array}$ & $\mathrm{K}_{10}$ & $\mathrm{~K}_{10}=\frac{\mathrm{O}_{\text {HAдRK }}}{\mathrm{O}_{\text {3ar }}}$ \\
\hline Прогресивність обладнання & $\mathrm{K}_{11}$ & $\mathrm{~K}_{11}=\frac{\mathrm{O}_{\text {mp }}}{\mathrm{O}_{\text {sar }}}$ \\
\hline Показник модернізації обладнання & $\mathrm{K}_{12}$ & $\mathrm{~K}_{12}=\frac{\mathrm{O}_{\mathrm{m}}}{\mathrm{O}_{3 \mathrm{ar}}}$ \\
\hline Коефіцієнт введення нової техніки & $\mathrm{K}_{13}$ & $\mathrm{~K}_{13}=\frac{\mathrm{OB} \Phi_{\mathrm{H}}}{\mathrm{OB} \Phi}$ \\
\hline \multicolumn{3}{|c|}{ Інформаційна складова } \\
\hline Витрати на інформаційну діяльність & $\mathrm{K}_{14}$ & $\mathrm{~K}_{14}=\frac{\mathrm{B}_{\text {пд }}}{\mathrm{Y}_{\text {нддкR }}}$ \\
\hline $\begin{array}{l}\text { Коефіцієнт персоналу, зайнятого } \\
\text { інформаційною діяльністю }\end{array}$ & $\mathrm{K}_{15}$ & $\mathrm{~K}_{15}=\frac{\mathrm{Ч}_{\text {घд }}}{\mathrm{\Psi}_{\text {ндДКр }}}$ \\
\hline \multicolumn{3}{|c|}{ Ринкова складова } \\
\hline Показники освоєння нової продукції & $\mathrm{K}_{16}$ & $\mathrm{~K}_{16}=\frac{\mathrm{BP}_{\text {uH }}}{\mathrm{BP}_{\text {3ar }}}$ \\
\hline $\begin{array}{c}\text { Доля інноваційної продукції в загальному } \\
\text { обсязі промислової продукції }\end{array}$ & $\mathrm{K}_{17}$ & $\mathrm{~K}_{17}=\frac{V_{\mathrm{UH}}}{V_{\text {sar }}}$ \\
\hline Рентабельність інноваційної продукції & $\mathrm{K}_{18}$ & $\mathrm{~K}_{18}=\frac{\mathrm{P}_{\mathrm{uH}}}{\mathrm{M}_{3 a r}}$ \\
\hline $\begin{array}{c}\text { Показник конкурентоспроможності нової } \\
\text { продукції }\end{array}$ & $\mathrm{K}_{19}$ & $\mathrm{~K}_{19}=\frac{\coprod_{\mathrm{i}}}{\coprod_{\mathrm{koHkyp}}}$ \\
\hline
\end{tabular}

Складено автором на основі [6]

Після комплексної оцінки інноваційного потенціалу підприємства необхідно визначитись який саме шлях розвитку потрібно обрати для підприємства для забезпечення його безперервного та ефективного розвитку.

Аналізуючи соціально-економічну, політичну та екологічну ситуацію в країни, можна зробити висновок, що найефективнішим шляхом розвитку підприємств буде екологічно спрямований розвиток, який дасть змогу забезпечити підприємствам як економічну ефективність так і соціальну активність. Неабияка роль в управлінні екологічно спрямованим інноваційним розвитком належить визначенню ефективності запроваджуваних методів, інструментів, стратегій, підходів. Крім того, екологічно спрямований 
інноваційний розвиток тісно пов'язаний із соціально-економічною політикою держави, яка через систему методів стимулювання і регулювання здійснює управління формуванням соціально-орієнтованої ринкової економіки [7]. Тому існує необхідність визначення потреби промислового підприємства у впровадженні екологічних інновацій. Для цього необхідно розрахувати систему показників екологічності виробничих процесів промислового підприємства, яка відображена у вигляді таблиці (табл. 2):

Таблиця 2

\section{Система показників екологічності виробничих процесів}

\begin{tabular}{|c|c|c|}
\hline № & Назва показника & Формула \\
\hline 1 & $\begin{array}{l}\text { Показник споживання } \\
\text { енергетичних ресурсів }\end{array}$ & $\begin{array}{l}\qquad \mathrm{K}_{\mathrm{B}}=1-\frac{\mathrm{E}}{\Pi}, \mathrm{K}_{\mathrm{B}} \rightarrow 1 \\
\text { Е - вартість усіх енергоносіїв, які використовуються у } \\
\text { виробництві, грн.; } \\
\text { П - кількість виготовленої продукції, грн. }\end{array}$ \\
\hline 2 & $\begin{array}{l}\text { Показник споживання } \\
\text { матеріальних ресурсів }\end{array}$ & $\begin{array}{l}\mathrm{K}_{\mathrm{M}}=1-\frac{\mathrm{M}}{\Pi}, \mathrm{K}_{\mathrm{M}} \rightarrow 1 \\
\mathrm{M}-\text { вартість сировини } \quad \text { i матеріалів, які } \\
\text { використовуються у виробництві, грн.; } \\
\text { П- вартість виготовленої продукції, грн. }\end{array}$ \\
\hline 3 & $\begin{array}{c}\text { Показник збиткоємності } \\
\text { продукції }\end{array}$ & $\begin{array}{l}\mathrm{K}_{\mathrm{s}}=1-\frac{3+\Phi}{\Pi}, \mathrm{K}_{s} \rightarrow 1 \\
\text { 3- сума нарахованих зборів за забруднення НПС, грн.; } \\
\text { Ф- фінансові санкції за порушення природоохоронного } \\
\text { законодавства, грн.; } \\
\text { П - вартість виготовленої продукції, грн. }\end{array}$ \\
\hline 4 & $\begin{array}{c}\text { Показник споживання } \\
\text { водних ресурсів }\end{array}$ & $\begin{array}{l}\qquad \mathrm{K}_{\mathrm{cт}}=1-\frac{\mathrm{B}_{\mathrm{cT}}}{\Pi}, \mathrm{K}_{\mathrm{cT}} \rightarrow 1 \\
\text { Вст - загальна кількість стічних вод; } \\
\text { П - обсяг виготовленої продукції. }\end{array}$ \\
\hline
\end{tabular}

Складено автором на основі [8]

Розрахувавши ці показники можна одразу побачити чи необхідно підприємству вдосконалення на основі екологічних інновацій. Якщо таке вдосконалення необхідне, то в якій саме сфері впровадження екологічних інновацій повинно бути першочерговим.

Визначивши потребу підприємства у впровадженні екологічних інновацій, необхідно обрати метод вдосконалення підприємства. Сьогодні методів вдосконалення підприємств за допомогою еко-інновацій в Україні 
стає все більше. Виділимо низку програм, які дадуть змогу підприємствам ефективно функціонувати в сучасних умовах господарювання (табл. 3).

Таблиця 3

Екологічні програми, які сприятимуть соціально-економічному розвитку підприсмств

\begin{tabular}{|c|c|}
\hline Назва програми & Характеристика \\
\hline Еко-офіс & $\begin{array}{l}\text { концепція управління організацією, яка допомагає зменшити іiї } \\
\text { негативний вплив на навколишнє природне середовище } \\
\text { шляхом максимального збереження ресурсів та енергії і } \\
\text { зменшення кількості відходів. Сприяє підвищенню обізнаності } \\
\text { співробітників про екологічно раціональне споживання }\end{array}$ \\
\hline Екологічна сертифікація & $\begin{array}{l}\text { система еко-маркування для закладів, які мають за мету } \\
\text { сприяти зменшенню тиску на природне середовище від } \\
\text { експлуатації промислових об‘єктів шляхом визначення та } \\
\text { стимулювання розвитку корисних ініціатив і екологічно } \\
\text { дружніх методів управління }\end{array}$ \\
\hline $\begin{array}{c}\text { Альтернативна } \\
\text { енергетика }\end{array}$ & $\begin{array}{l}\text { використання альтернативних джерел споживання енергії } \\
\text { підприємствами, таких як вітроустановки, біогазові станції, } \\
\text { сонячні установки, малі гідростанції та інш. }\end{array}$ \\
\hline Проект WASTEred & $\begin{array}{l}\text { спрямований на сприяння використанню і заохочення } \\
\text { проникнення на ринок LODOred, нового ECO-інноваційного } \\
\text { продукту для того, щоб скоротити велику кількість стічних } \\
\text { вод, що утворюються в очисних спорудах. Очікуване зниження } \\
\text { призведе до зниження впливу на навколишнє середовище, а } \\
\text { також витрати, пов'язані з управлінням мулу. (найчастіше } \\
\text { використання у харчовій промисловості) }\end{array}$ \\
\hline
\end{tabular}

Складено автором на основі $[10,11,12]$

Використання таких програм дозволить підприємству бути соціально активною та екологічно відповідальною компанією, що $є$ необхідними умовами для ефективного функціонування підприємства.

Висновки. Отже, аналізуючи весь вище викладений матеріал можна зробити висновок, що технологічний розвиток в сучасних умовах господарювання має важливе значення, тому що забезпечує можливість постійного оновлення продукції, підвищення ії якості, тим самим підвищуючи конкурентоспроможність підприємства i його продукції на ринку. Тому питанню технологічного розвитку необхідно приділити першочергову увагу. На нашу думку одним 3 найефективніших шляхів технологічного розвитку $\epsilon$ впровадження еко-інновацій на промислових підприємствах. Це забезпечить підприємству конкурентні переваги на ринку, дозволить заощаджувати, а також бути соціально відповідальним та екологічно дружнім підприємством.

Науковою новизною проведеного дослідження слід вважати обгрунтування доцільності та шляхів технологічного розвитку промислового 
підприємства, яке буде грунтуватись на переході до еколого-інноваційного розвитку.

В подальшому дослідження будуть присвячені пошуку найефективніших шляхів розвитку, які будуть ефективними не тільки в розрізі одного підприємства, а й для галузі в цілому.

\section{Література:}

1. Федулова Л. І. Стратегія технологічного розвитку: мікроекономічний підхід [Електронний ресурс] / Л. І. Федулова // Проблеми економіки та управління. - Л. : Видво Нац. ун-ту "Львів. політехніка". - 2008. - Режим доступу до ресурсу: http://ena.lp.edu.ua:8080/handle/ntb/1398.

2. Шевлюга О. Г. Дослідження впливу технологічних інновацій на ринок технологій $\mathrm{i}$ розвиток підприємства [Електронний ресурс] / О. Г. Шевлюга, О. М. Олефіренко // Вісник СумДУ. Серія «Маркетинг і менеджмент інновацій» №4.. - 2011. - Режим доступу до ресурсу: http://mmi.fem.sumdu.edu.ua/.

3. Наукова та інноваційна діяльність в Україні: Статистичний збірник [Електронний ресурс] // Державна служба статистики України. - 2014. - Режим доступу до ресурсу: http://www.ukrstat.gov.ua/.

4. Гонтарева I. В. Оцінка потенціалу техніко-технологічної бази промислового підприємства [Електронний ресурс] / I. В. Гонтарева // Вісник СумДУ. Серія «Економіка» №4. - 2011. - Режим доступу до ресурсу: http://irbis-nbuv.gov.ua/cgibin/irbis_nbuv/cgiirbis_64.exe\%3FC21COM\%3D2\%26I21DBN\%3DUJRN\%26P21DBN\%3 DUJRN\%26IMAGE_FILE_DOWNLOAD\%3D1\%26Image_file_name\%3DPDF/VSU_ekon_ 2011_4_20.pdf.

5. Рачинська Г. В. Оцінювання рівня технологічного розвитку [Електронний ресурс] / Г. В. Рачинська, Л. С. Лісовська // Національний університет «Львівська політехніка» кафедра менеджменту організацій - Режим доступу до ресурсу: Режим доступу: http://ena.lp.edu.ua:8080/bitstream/ntb/11116/1/40.pdf.

6. Лощина Л. В. Комплексна оцінка інноваційного потенціалу підприємства: теоретикометодичні підходи [Електронний ресурс] / Л. В. Лощина, В. М. Мілашенко // м. Суми, Державний вищий навчальний заклад «Українська академія банківської справи Національного банку України. - 2004. - Режим доступу до ресурсу: http://dspace.uabs.edu.ua/bitstream/123456789/1234/1/comprehensive\%20assessment\%20of $\% 20$ the\%20innovation.pdf.

7. Прокопенко О. В. Організаційно-економічний механізм управління екологічно спрямованим інноваційним розвитком [Електронний ресурс] / О. В. Прокопенко, Т. В. Касьяненко // Вісник СумДУ. Серія «Економіка» - Режим доступу до ресурсу: http://essuir.sumdu.edu.ua/bitstream/123456789/16112/1/mehanizm.pdf.

8. Хобта В. М. Оцінка екологічних аспектів діяльності машинобудівного підприємства [Електронний ресурс] / В. М. Хобта, О. Ю. Руднєва // ДВНЗ «Донецький національний технічний університет» - Режим доступу до ресурсу: http://ea.donntu.edu.ua:8080/jspui/bitstream/123456789/3783/1/s4_04_hobta.pdf

9. Мала Н. Т. Економічний розвиток підприємства: планування та моделювання [Електронний ресурс] / Н. Т. Мала, О. В. Грабельська // Національний університет «Львівська політехніка». - 2012. - Режим доступу до ресурсу: http://ena.lp.edu.ua:8080/bitstream/ntb/17259/1/5-22-28.pdf. 
10. Офіційний сайт проекту «WASTEred» [Електронний ресурс] - Режим доступу до pecypcy: http://www.wastered.eu/.

11. Офіційний сайт органу екологічної сертифікації та маркування [Електронний ресурс] Режим доступу до ресурсу: http://www.ecolabel.org.ua/.

12. Маслюківська О. П. Концепція зеленого офісу: рекомендації для організацій щодо екологічно дружнього ставлення до навколишнього середовища / О. П. Маслюківська, Н. I. Шульга. - Київ: Університетське видавництво ПУЛЬСАРИ, 2007. - (ISBN 978-9668767-67-8). 